\title{
William JAMES, A Pluralistic Universe
}

edited and introduced by H. G. Callaway, Newcastle upon Tyne, Cambridge Scholars Publishing, 2008

\section{Michela Bella}

\section{(2) OpenEdition}

\section{Journals}

Electronic version

URL: http://journals.openedition.org/ejpap/756

DOI: $10.4000 /$ ejpap.756

ISSN: 2036-4091

\section{Publisher}

Associazione Pragma

\section{Electronic reference}

Michela Bella, «William JAmEs, A Pluralistic Universe », European Journal of Pragmatism and American Philosophy [Online], IV-2 | 2012, Online since 24 December 2012, connection on 23 September 2020 URL : http://journals.openedition.org/ejpap/756 ; DOI : https://doi.org/10.4000/ejpap.756

This text was automatically generated on 23 September 2020 .

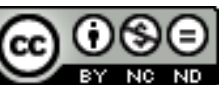

Author retains copyright and grants the European Journal of Pragmatism and American Philosophy right of first publication with the work simultaneously licensed under a Creative Commons AttributionNonCommercial-NoDerivatives 4.0 International License. 


\section{William JAMES, A Pluralistic Universe}

edited and introduced by H. G. Callaway, Newcastle upon Tyne, Cambridge Scholars Publishing, 2008

\section{Michela Bella}

\section{REFERENCES}

William JAMEs, A Pluralistic Universe, edited and introduced by H. G. Callaway, Newcastle upon Tyne, Cambridge Scholars Publishing, 2008

1 This recent edition of A Pluralistic Universe (1909), edited and introduced by H. G. Callaway, is a recovery and a close examination of James's pluralism. The editor proposes a study edition of this famous text, which is the latest book published during James' lifetime. His long preface, his work on lexicon, his notes, and the attention he gives to the historical background are great tools to pragmatism students and scholars for critical reading.

In this book, in many ways James argues against absolute monism and explains his promotion of Pluralism, very well orchestrating the rhythm of partes destruens and pars construens in his discourse. His strategy is to make his audience more and more convinced about the insufficiency of idealism, as to give them concrete consistency of the pluralistic alternative. He starts to notice that the idealistic Weltanschauung cannot fully satisfy our need of feeling at home in the world, and it is this necessary to justify James's attempt to support and encourage other possible choices. In fact, although empiricism and rationalism have - in a pantheistic sense - a spiritualistic vision in common, there is a fundamental discordance between these two philosophical and temperamental portraits. The former is, indeed, defined by James as "the habit of explaining wholes by parts," and the latter as the opposite "habit of explaining parts by wholes" (5). As it is well known, the text moves from the assumption that our ways of looking at the world are built on aesthetical and practical interests and that we reclaim to the consequences of our preferences a necessitatis ratione. James maintains that we all are led by beliefs that we try to support and justify in order to keep our beliefs going. In 
this process, he says, a certain finality always appears to be prior to other reasons, since our 'will to believe' is strictly connected to our interested human nature.

The book is based on a series of lectures James held at Oxford University in 1908. Callaway focuses his attention on the continuation between James and Ralph Waldo Emerson, both of whom had a main role in exporting American philosophy in England. The editor also gives an important account of the historical framework of Hibbert Lectures, considering the political and cultural context of United States before the first World War. At that time British imperialism and European nationalism were at their peak, and European countries contended one with another for US powerful naval army's alliance. In the first conference James recollected USA and England common cultural backgrounds and wished they returned to their common philosophical routes as classical empiricism was -, identifying their common enemy with the pedantic and over-technical German academic way of philosophizing. Callaway remarks on the political tune running through the text, and he points out the famous and ambiguous similarity proposed by James, the one saying that the pluralistic world is "more like a federal republic than like an empire or a kingdom" (195).

\section{Pluralism, Humanism and Nominalism}

4 The philosophical critique to absolute monism is, however, the book's very guideline. James attacks such a theory both as it was acknowledged by Idealists of the end of the XIX century and as it was sustained by Hegel. In On some Hegelisms (1882) James had already expressed some objections to idealism and his ongoing questions seemed to be whether ideal identity or concrete variety is the basis of our vision of the universe. He now attempts to show pluralism as a pursuable view against rationalist metaphysics and its main implications (determinism and perfectionism).

As Callaway very well underlines, James is mainly concerned with the nature of relations: he wants to state the possibility of external relations, which were completely excluded from monistic idealism. Absolute idealists didn't believe a universe made up of "collective or addicted form" is real, but they thought there could only be what James called a "block-universe." This refers to a reality thoroughly and systematically predetermined in its parts from the all. In his discussion James is, of course, referring to metaphysics quarrels on the nature of universals, but his socio-political concerns can also be detected in his arguments. Callaway tries to separately follow these two lines of analysis - theoretical and political - of the book, beginning with a critical inquiry of the identitarian implications of James's pluralism on theoretical and social levels. According to pluralism:

there may ultimately never be an all-form at all, that the substance of reality may never get totally collected, [...] and that a distributive form of reality, the each-form, is logically as acceptable and empirically as probable as the all-form commonly acquiesced in as so obviously the self-evident thing. The contrast between these two forms of a reality which we agree to suppose substantially spiritual is the topic of this course of lectures. (21)

6 James's pluralistic view contests that an absolute logical union of reality could never be possible, and he makes clear his thought denying the possibility of exclusive "internal relations," which means relations only internal to their terms. Conceptual identity can never fully grasp reality in all of its variety. Such a view should be also considered the 
core of James nominalist temptation. As Callaway sustains, nominalism is in accordance with classic pragmatist fallibilism, which is a methodological and theoretical view through which our theories and scientific laws should always leave margins for growth and revision. There is nothing in our universe that can be considered definitive a priori, neither in our scientific knowledge, nor in our social bonds or identitarian relations. The pluralist suggests that reality is not a complete unity, all connected and perfect, but there is always something escaping from our knowledge: something "not yet considered." Pragmatist anti-essentialism and humanism, as clearly disclosed in the preface of this edition, are important to corroborate the conviction that doesn't exist such a previous nature of the world, something ready-made and absolute; it is time to figure out another image of human relations where ideas don't fall down from above, but human beings are "real causes in nature."

7 According to one of James's most persistent and original claims of all his psychological and philosophical thought, potentialities of human agency should be considered the center of our natural dimension. Callaway proposes a careful analysis of James's critique to what is called 'vicious intellectualism' - as it is variously declined from absolute monists -, which represents a very helpful and convincing contribution of his preface to discussions on the text. By the words 'vicious intellectualism' James meant:

The treating of a name as excluding from the fact named what the name's

definition fails positively to include, is what I call 'vicious intellectualism.' (38)

Such a "radical rationalism" is at odds with James' radical empiricism hence the priority he gave to perception compared to the conceptual dimension. James took into account many idealist authors and bitterly criticized their fallacies. They are all used to go from one extreme to another suggesting false dilemmas, thus reducing ad absurdum the thesis they disagree with. They mean only absolute independence by accident, so that if relations have to be accidental, these authors can easily understand that it is impossible to connect parts with one each other. In reverse, assuming that relations can only be essential, they can say that the absolute union of all things is necessary. In particular James analyses Lotze, Royce and Bradley's arguments. Lotze attempted to develop a spiritualistic conception of reality, gaining hints to Leibniz's monadism and pluralism. But, in the end he grew so concerned about avoiding the same pluralist outcomes of his own theory that he tried to recover the Unity of all beings and processes through his analysis of the empirical nature of interaction. James retains Lotze's concept of interaction among independent elements as a pure verbal operation, it is a vain attempt to introduce the logical level of reasoning to avoid contradiction in his theory. ${ }^{1}$ James did not believe such an abstract and speculative approach was required. Reality - he said - is already coherent and he wonders why we should look for a noumenic identity to fund and explain the phenomenic continuity.

His comparison with Hegel's theories, started in his article published in 1882 on "Mind" and later in The Will to Believe (1897), is the true background of James's thought about pluralism. He is now definitively refusing to assume knowledge to be total and complete, as far as to negate everything, which is not positively included in the conceptual knowledge of something. In James's view, this kind of double negation activates the Hegelian dialectic process:

Now Hegel himself, in building up his method of double negation, offers the vividest possible example of this vice of intellectualism. Every idea of a finite thing is of course a concept of that thing and not a concept of anything else. But Hegel treats this not being a concept of anything else as if it were equivalent to the concept of 
anything else not being, or in other words as if it were a denial or negation of everything else. Then, as the other things, thus implicitly contradicted by the thing first conceived, also by the same law contradict it, the pulse of dialectic commences to beat and the famous triads begin to grind out the cosmos. (66)

10 James uses the phrase "vicious intellectualism" to explain this general defect of absolutistic reasoning. He believes the Hegelian system is based on the identity of contradictories' principle and the principle of totality. This second principle states that to know one part, it is necessary to know the totality of that part. In 1882 James underlined the 'abstractness' and logical fallacies of Hegelian definitions which the famous philosopher made to reach his conclusions. James was particularly upset by the fact that Hegel did not distinguish the respect under which he used terms. In regard to this critique, Callaway points out pivotal passages where James's nominalist drift is undeniable. He is also interested in stressing James' nominalist inclination to remark a great distinction between the view of the American philosopher and his famous colleague, R. W. Emerson.

\section{James and Emerson}

11 The comparison between James and Emerson is a very appealing feature of Callaway's preface and, of course, his research interests. ${ }^{2}$ The great work he did on lexicon and historical context is valuable, it allows students to approach these texts more easily. Here he states that despite their discontinuity about nominalism, both James and Emerson sustained, more or less consciously, forms of pluralism. The orator of Concord was a good friend of James's father, their friendship was due to their common ties with Transcendentalism and in fact common to both Emerson and James was a certain emphasis on spiritual rebirth and the aversion to passive fatalism. Notwithstanding, James considered Emerson's idea of Absolute so close to the Hegelians' one and he did not feel at ease with such an idea of transcendence, suggesting a reality which is 'unexperiencable.' As a matter of fact, James associates idealistic absolutism with some kind of unavoidable predetermination. And, because of this linkage, he just could not easily hold the attention Emerson gave to individuality together with his faith in a divine plan.

12 In Callaway's closer analysis, Emerson is an anti-predestinationalist and a convinced anti-nominalist. The Emersonian meliorism was routed in his realistic thinking of natural and moral law, which he considered to be in fieri. Such a belief contrasts with the nominalist temptation we recognize in James's pluralism and in his psychological interests, as well. Callaway also points out that with James there is neither the same stress Emerson put on Law, nor the same attention he gave to connections between human individual freedom and our growing skill in understanding Laws.

13 James and Emerson clearly shared a similar attention to individuality as much as Callaway can talk about radical pluralism for both of them. He also considers how Emerson was less conscious of his own pluralistic outcomes than, of course, James was. Moreover, their perspectives remain different in regards to the rule they gave to action: James focused on the importance of human activity to freedom as much as Emerson emphasized its theoretical development, though Emerson maintained in his protopragmatism style that 'every thought is for the sake of action.' In a nutshell, Callaway considers Emerson to be still anchored in Platonic and Neo-Platonic tradition, while 
James decidedly kept away from that philosophical view. In conclusion, it is also important to remember the critical attitude these two thinkers shared towards contemporary forms of political imperialism.

\section{Pluralism in United States of America nowadays}

14 The alternative between absolutism and pluralism, which James strived to mark out at a philosophical level, can also be considered a very useful tool to investigate contemporary American socio-political order and its historical issues. In this spirit, on a political level, Callaway retains the quest for an ideal "organic unity" to be taken primarily as a philosophical mistake: we need to keep in mind that this idea is just an insidious and dangerous abstraction which does not help the USA to gain concrete equilibrium between the unity of the country and the diversity of its constitutive elements. From James's achievements on, variety has always been retained a source for America, which is a country that is from its foundation searching for a balance between nationalism and federalism. As James stated, the "ever not quite" should be a monitum stating that a space for difference and its growth is always to be preserved. Even if difference is not a good in itself, we can anyway consider it a potentiality to protect: only through difference we can develop and enrich our cultural and political exchanges, hence bringing meliorisms into our society.

American national identity is not set on models of ethnic or religious routes, it has never been a homogeneous unity but a created one: "One from Many." Such an historical formation allows American society how important it is to combine the best qualities of every single group and persons through democratic procedures. It also permits them to achieve new goals which couldn't be realized independently. As Callaway highlights, there is a nominalist tendency first in James and then in Dewey stressing the experiential and individual side in regards to the legal one. This does not mean democracy can be morally vacant. Instead, it should always be ruled and led from institutions. A democratic society needs laws to guarantee our possibility of living together, but it also needs uniformity and suppression of pluralities to be avoided. If constitution preserves freedom and diversities, it is also useful to control their excesses. Callaway retains constitutional tradition to be a shelter against any possible excess committed by the majority of the Congress. He considers auto-formation and civil organization - often based on models of religious congregations - to be fundamental. In the end it is important to notice, as Callaway does, that democracy and pluralism need a ground of shared moral values to be preserved, because institutional procedures alone cannot totally control neither forms of excessive centralization of power nor lobbyists' pressures. 


\section{BIBLIOGRAPHY}

EMERSON R. W., (2006), The Conduct of Life: A Philosophical Reading, H. G. Callaway (ed.), University Press of America.

EMERON R. W., (2008), Society and Solitude, Twelve Chapters. A New Study Edition with Notes, Philosophical Commentary, and Historical Contextualization, H. G. Callaway (ed.), Edwin Mellen Press. KRAUSHAAR O. F., (1939), “Lotze as a Factor in the Development of James's Radical Empiricism and Pluralism," The Philosophical Review, 48, 5, 455-71.

\section{NOTES}

1. Kraushaar 1939.

2. Emerson 2006, and 2008.

\section{AUTHORS}

\section{MICHELA BELLA}

Università di Roma Tre

michela.bella[at]uniroma3.it 